\title{
Insulation workers in Belfast. 2. Morbidity in men still at work
}

\author{
JEAN H. M. LANGLANDS, WILLIAM F. M. WALLACE, and \\ MARION J. C. SIMPSON \\ Respiratory Investigation Centre, Belfast City Hospital, Lisburn Road, Belfast ; \\ Department of Physiology, Medical Biology Centre, Lisburn Road, Belfast; \\ and Department of Therapeutics and Pharmacology, Queen's University, Belfast
}

\begin{abstract}
Langlands, Jean H. M., Wallace, W. F. M., and Simpson, Marion J. C. (1971). Brit. J. industr. Med., 28, 217-225. Insulation workers in Belfast. 2. Morbidity in men still at work. Two hundred and fifty-two $(93 \%)$ of the insulation workers in Belfast were examined by chest $x$-ray, questionnaire, clinical examination, and tests of respiratory function. The frequency of chest $x$-ray abnormality, lung field or pleural, increased from $13 \%$ in men who had worked for less than 10 years to $85 \%$ in men who had worked for 30 or more years in the industry. Pleural calcification was found in $15 x$-rays. There was evidence suggesting that some men had pleural fibrosis or calcification due to exposure to asbestos in childhood. Rales were present in $61 \%$ and clubbing in $11 \%$ of men with lung field abnormality, but these were not common when the $x$-rays showed only pleural abnormality. Where the lung fields were involved there was a restrictive defect with impairment in lung function most marked in the forced vital capacity and single breath carbon monoxide transfer factor, but where the pleura was involved without lung field involvement there was a tendency to impairment of ventilatory function with a normal transfer factor. Cigarette smoking was associated with a greater impairment of lung function than was $x$-ray abnormality.
\end{abstract}

\begin{abstract}
Asbestos insulation has been used for many years in the Belfast shipyards. Since the second world war it has also been used increasingly in the construction of large buildings such as factories and hospitals. All insulation of ships or buildings in Belfast is subcontracted to a number of firms which specialize in this work. The present survey was undertaken to assess the effect on health of exposure to asbestos in men currently working in the trade, and to obtain a record which will form a baseline for a follow-up of this group of men.
\end{abstract}

\section{Methods}

The men were contacted from lists given by their trade union and their employers. Two hundred and seventy-two men were working as insulators (apprentices, trained insulators, and insulator's labourers) during the present investigation and results from $252(93 \%)$ are available for analysis. These include the 50 men in the series reported in study 1 (Wallace and Langlands, 1971). There were 17 refusals and in three men the results were incomplete. Thirteen women were employed by one of the firms in making asbestos or fibreglass quilts (known as 'mattresses') for insulation work. The women were all seen but their results are not included in the main analysis.

The clinical history was taken by one of the authors (M.S.), who is a social worker, using the M.R.C. long respiratory questionnaire with special emphasis on the industrial history (Medical Research Council, 1960). It was not possible to obtain any information about relative exposure to different types of asbestos or to assess the time each individual had spent working with asbestos as distinct from other material, such as fibreglass, used in insulation, but the men were asked whether they had ever done 'limpet spraying' of asbestos which exposes the operator to a high concentration of asbestos dust. A 
technically satisfactory chest $x$-ray was taken of all subjects. Chest $x$-rays were read by two observers (J.O.Y.C. and P.C.E.) and then by an independent observer (J.C.G.) using an adaptation of the I.L.O. classification of pneumoconiosis (Sluis-Cremer and Theron, 1965). The final reading was agreed by all three observers reading the films together. Chest $x$-rays were classified as being within normal limits or showing one or both of two types of abnormality due to asbestos: a lung field abnormality (abnormal reticulation, linear shadows or fine nodulation) and a pleural abnormality (pleural fibrosis and/or calcification). The methods of clinical examination, measurement of the hyponychial angle, examination of the sputum for asbestos bodies, and measurement of the forced expiratory volume in one second $\left(F E V_{1.0}\right)$, forced vital capacity (FVC), peak flow rate (PFR), total lung capacity (TLC) and its subdivisions, and single breath carbon monoxide transfer factor $(\mathrm{Tl})$ have been described in study 1 . The diffusing capacity of the pulmonary membrane (Dm), pulmonary capillary blood volume (Vc), and arterial $\mathrm{Po}_{2}$ were not measured in all the men of the present series, and consideration of these has been omitted. Predicted values were obtained from nomograms given by Cotes (1965) except for transfer factor where the data of Hunt (1965) gave better agreement with results obtained from normal subjects with our equipment. The presence of asbestos warts or a history of having had them was noted, and two observers independently recorded the presence or absence of finger clubbing.

\section{Results}

Chest $x$-rays

The proportion of men with abnormal chest $x$-rays increased with age and with the number of years worked in the industry (Tables 1 and 2). In men grouped according to their present age the average age of entering into the industry was five years younger in men with lung field abnormality in their chest $x$-rays, and these men therefore had a longer exposure to asbestos than men of the same age group with normal chest $x$-rays (Table 3 ). The relationship

TABLE 1

Abnormal Chest X-rays in Insulation Workers RELATED TO AGE

\begin{tabular}{c|c|c|c|c}
\hline Age $(y r)$ & $\begin{array}{c}\text { Total no. } \\
\text { of } x \text {-rays }\end{array}$ & $\begin{array}{c}\text { Pleural } \\
\text { abnor- } \\
\text { mality only }\end{array}$ & $\begin{array}{c}\text { Lung field } \\
\pm \text { pleural } \\
\text { abnor- } \\
\text { mality }\end{array}$ & $\begin{array}{c}\text { Total no. } \\
\text { of abnor- } \\
\text { mal x-rays }\end{array}$ \\
\hline up to 19 & 20 & 0 & 0 & 0 \\
$20-29$ & 36 & 5 & 1 & $6(17 \%)$ \\
$30-39$ & 53 & 5 & 5 & $10(19 \%)$ \\
$40-49$ & 77 & 10 & 23 & $33(43 \%)$ \\
$50-59$ & 47 & 5 & 21 & $26(60 \%)$ \\
over 60 & 19 & 3 & 12 & $15(80 \%)$ \\
\hline Total & 252 & 28 & 62 & 90 \\
\hline
\end{tabular}

TABLE 2

Abnormal Chest X-Rays in Insulation Workers RELATED TO YEARS OF WORK

\begin{tabular}{c|c|c|c|c}
\hline $\begin{array}{c}\text { Years } \\
\text { as an } \\
\text { insulator }\end{array}$ & $\begin{array}{c}\text { Total } \\
\text { no. of } \\
x \text {-rays }\end{array}$ & $\begin{array}{c}\text { Pleural } \\
\text { abnormality } \\
\text { only }\end{array}$ & $\begin{array}{c}\text { Lung field } \\
\pm \text { pleural } \\
\text { abnormality }\end{array}$ & $\begin{array}{c}\text { Total no. } \\
\text { of abnormal } \\
x \text {-rays }\end{array}$ \\
\hline $0-9$ & 55 & 5 & 2 & $7(13 \%)$ \\
$10-19$ & 103 & 12 & 16 & $28(29 \%)$ \\
$20-29$ & 75 & 10 & 29 & $39(52 \%)$ \\
over 30 & 19 & 1 & 15 & $16(85 \%)$ \\
\hline
\end{tabular}

TABLE 3

Abnormal Chest X-rays in Insulation Workers related to Present Age and to Mean Age of STARTING INSULATION WORK

\begin{tabular}{c|c|c|c}
\hline & \multicolumn{2}{|c}{ Mean age $(y r)$ starting insulation work } \\
\cline { 2 - 4 } $\begin{array}{c}\text { Present } \\
\text { age } \\
(y r)\end{array}$ & $\begin{array}{c}\text { Normal } \\
\text { x-rays }\end{array}$ & $\begin{array}{c}\text { Pleural } \\
\text { abnormality } \\
\text { only }\end{array}$ & $\begin{array}{c}\text { Lung field } \\
\text { 土 pleural } \\
\text { abnormality }\end{array}$ \\
\hline $20-29$ & 16.8 & $15 \cdot 5$ & - \\
$30-39$ & 20.9 & $21 \cdot 8$ & $15 \cdot 8$ \\
$40-49$ & $25 \cdot 3$ & $24 \cdot 8$ & 20.6 \\
$50-59$ & $34 \cdot 3$ & $30 \cdot 8$ & $28 \cdot 4$ \\
Over 60 & - & - & $33 \cdot 1$ \\
\hline
\end{tabular}

Data about groups of less than five men are omitted.

between the type of chest $x$-ray abnormality and the number of years since starting work in the industry is shown in Table 4. There was pleural calcification in $15 x$-rays. Ten men had pleural fibrosis and lung field abnormality in addition to the pleural calcification: they had worked for 25 or more years as insulation workers. Five men had pleural calcification with or without pleural fibrosis but no lung field abnormality and had worked for less than 25 years as insulation workers; two of these, aged 22 and 23

\section{TABLE 4}

TyPe of Chest X-RAy AbNormality In Insulation WORKERS RELATED to YeARS OF WORK

\begin{tabular}{|c|c|c|c|c|c|}
\hline \multirow{2}{*}{$\begin{array}{l}\text { Lung field } \\
\text { abnormality }\end{array}$} & \multicolumn{2}{|c|}{ Pleural abnormality } & \multirow{2}{*}{$\begin{array}{l}\text { No. } \\
\text { of men }\end{array}$} & \multicolumn{2}{|c|}{$\begin{array}{c}\text { Years as an } \\
\text { insulator }\end{array}$} \\
\hline & Calcification & Fibrosis & & Mean & Range \\
\hline $\begin{array}{l}\text { No } \\
\text { No } \\
\text { Yes } \\
\text { Yes } \\
\text { Yes }\end{array}$ & $\begin{array}{l}\text { No } \\
\text { Yes } \\
\text { No } \\
\text { No } \\
\text { Yes }\end{array}$ & $\begin{array}{c}\text { Yes } \\
\text { Yes/No } \\
\text { No } \\
\text { Yes } \\
\text { Yes }\end{array}$ & $\begin{array}{r}23 \\
5 \\
21 \\
31 \\
10\end{array}$ & $\begin{array}{l}18 \\
13 \\
21 \\
25 \\
35\end{array}$ & $\begin{array}{l}(9-44) \\
(6-23) \\
(7-39) \\
(10-45) \\
(25-48)\end{array}$ \\
\hline
\end{tabular}


years, who had worked for six and eight years respectively had bilateral diaphragmatic calcification without pleural fibrosis, and each had a father and an uncle who were insulation workers; the other three were aged 42,48 , and 74 years and had no relatives working in the industry. Of five men aged 20-29 years who had abnormal chest $x$-rays after less than 10 years' work in the industry, including the two with bilateral calcification, four with pleural but no lung field abnormality had two or more relatives who were insulation workers; the other had minimal lung field abnormality and had no relatives who were insulation workers. Insulation work is a family trade in Belfast, and 111 men in the survey had fathers, uncles, brothers or sons who worked or had worked in the industry. It is suggested that some young men in our series may have developed pleural calcification or fibrosis due to exposure in childhood to asbestos dust brought home on the clothes of a father or elder brother. Both the total time spent working as an insulation worker, and the time which has elapsed since the first exposure to asbestos, may be implicated in the development of $x$-ray abnormality. These were usually the same in our series, in which only 14 men had had periods in which they had done other work after entering the industry. The four women mattress makers who had worked longest, for between 14 and 21 years in the industry, had abnormal chest $x$-rays. All four had radiological lung field abnormality and three also had pleural abnormality, one with calcification. No man or woman had a bronchial carcinoma or mesothelioma detected at the time of the survey.

\section{Clinical findings}

The prevalence of symptoms and of clinical signs referable to the respiratory system for asbestos insulation workers aged up to 39 and aged 40 or over is shown in Table 5. Smoking habits were virtually identical in the younger and older men; the frequencies of cough, sputum, and wheeze were increased by about half and the frequency of dyspnoea on exertion was more than doubled in the older men. These symptoms must reflect in part the bronchial damage due to cigarette smoking and air pollution in any industrial population and, in the case of dyspnoea, the effect of ageing. More specific were the basal rales which were present in one-third of the older men, and which were suggestive of asbestosis in this group. In contrast there was very little difference between the younger and older men in the frequency of rhonchi.

Finger clubbing and the hyponychial angle Casts from both forefingers were available for 216 men: in the remaining 34 men the casts were not made or were unsuitable for measurement due to damage to the casts or to deformity such as badly bitten nails.
TABLE 5

Clinical Findings, Cigarette Smoking, Asbestos WARTS, AsBestos Bodies, AND EXPOSURE TO LIMPET SPRAYING IN INSULATION WORKERS

\begin{tabular}{l|rc|cc}
\hline & \multicolumn{4}{|c}{ Age (years) } \\
\cline { 2 - 5 } & \multicolumn{3}{|c|}{$<40$} & \multicolumn{2}{|c}{$40+$} \\
\hline No. of men & 109 & & 143 & \\
Rales & 7 & $(6 \%)$ & 48 & $(34 \%)$ \\
Rhonchi & 6 & $(6 \%)$ & 11 & $(8 \%)$ \\
Hyponychial angle $>205^{\circ}$ & $0 / 91$ & & $8 / 125$ & $(6 \%)$ \\
Mean R. hyponychial angle & $181^{\circ}$ & & $186^{\circ}$ & \\
Mean L. hyponychial angle & $182^{\circ}$ & & $187^{\circ}$ & \\
Dyspnoea grade 2 & 19 & $(17 \%)$ & 48 & $(34 \%)$ \\
& 7 & $(6 \%)$ & 31 & $(22 \%)$ \\
$\quad$ grade 3 to 5 & 26 & $(24 \%)$ & 79 & $(55 \%)$ \\
Cough & 45 & $(41 \%)$ & 98 & $(69 \%)$ \\
Sputum & 53 & $(49 \%)$ & 106 & $(74 \%)$ \\
Wheeze & 54 & $(50 \%)$ & 97 & $(68 \%)$ \\
Weather affects chest & 16 & $(15 \%)$ & 42 & $(29 \%)$ \\
Cigarette smokers & 75 & $(69 \%)$ & 105 & $(74 \%)$ \\
Cig. smokers $>25$ daily & 21 & $(19 \%)$ & 30 & $(21 \%)$ \\
Asbestos warts on hands & $57 / 109$ & $(52 \%)$ & $100 / 135$ & $(74 \%)$ \\
Asbestos bodies in sputum & $10 / 84$ & $(12 \%)$ & $37 / 119$ & $(31 \%)$ \\
Limpet spraying & 14 & $(13 \%)$ & 38 & $(27 \%)$ \\
& & & & \\
\hline
\end{tabular}

The hyponychial angle measured from the casts was $205^{\circ}$ or more in one or both forefingers in eight men representing 'definite clubbing', and 196 to $204^{\circ}$ in 16 men representing 'doubtful clubbing', by the criteria of Regan, Tagg, and Thomson (1967). The two observers agreed that there was clubbing in 14 men of whom six had 'definite clubbing' and four had 'doubtful clubbing' by angle measurements and four had a normal hyponychial angle of less than $196^{\circ}$. The mean hyponychial angle increased with age both in men with normal $x$-rays and in men with lung field abnormality, and it was greater in the left forefinger than in the right forefinger (Fig. 1). The difference between the fingers was more marked in the eight men with definite clubbing, in whom the mean hyponychial angle was $8^{\circ}$ greater in the left forefinger than in the right forefinger.

Asbestos bodies and asbestos warts One or more asbestos bodies were seen in smears of sputum from 48 out of 216 men from whom specimens were available, in 38 instances in the stained smear and in 29 instances in the unstained smear. One or more asbestos warts were present on the hands of 74 out of 234 men, and an additional 84 men had had them in the past but had got rid of them, usually after picking out the centres with a needle.

Respiratory function related to chest $x$-rays Some of the results are shown in Figure 2. Men with lung field abnormality had a lower mean $\mathrm{FEV}_{\mathbf{1 . 0}}, \mathrm{FVC}$, 


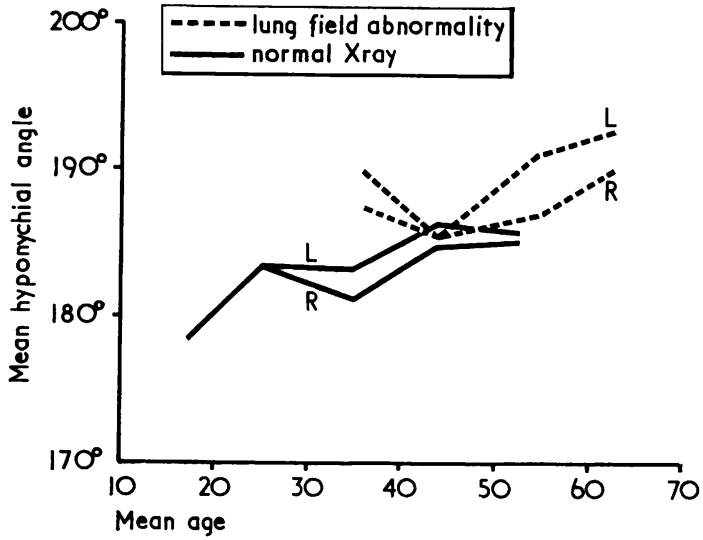

FIG. 1. Mean hyponychial angle of right and left forefingers related to age in insulation workers with normal chest $x$-rays and with lung field abnormality (with or without pleural abnormality).

TLC and Tl but a higher mean FEV $_{1.0} / F$ FC $\%$ and PFR than men with normal chest $x$-rays. Men with pleural abnormality only had a mean $\mathrm{Tl}$ similar to men with normal chest $x$-rays but a lower mean $\mathrm{FEV}_{1.0} / \mathrm{FVC} \%$ and PFR than either of the other groups.

Objective evidence of asbestosis In addition to abnormality of the chest $x$-ray, the following three features are suggestive of asbestosis: rales, finger clubbing, and a low FVC and/or a low Tl (defined arbitrarily as below $80 \%$ of predicted) in the presence of a normal $\mathrm{FEV}_{1.0} / \mathrm{FVC} \%$ (defined as above $80 \%$ of predicted). The frequency of these factors in the $x$-ray categories is shown in Table 6.

In the 62 men with $x$-ray abnormality of the lung fields, with or without pleural involvement, 50 $(81 \%)$ had one or more of the above additional factors and $25(40 \%)$ had two or more additional factors. In the 28 men with pleural involvement

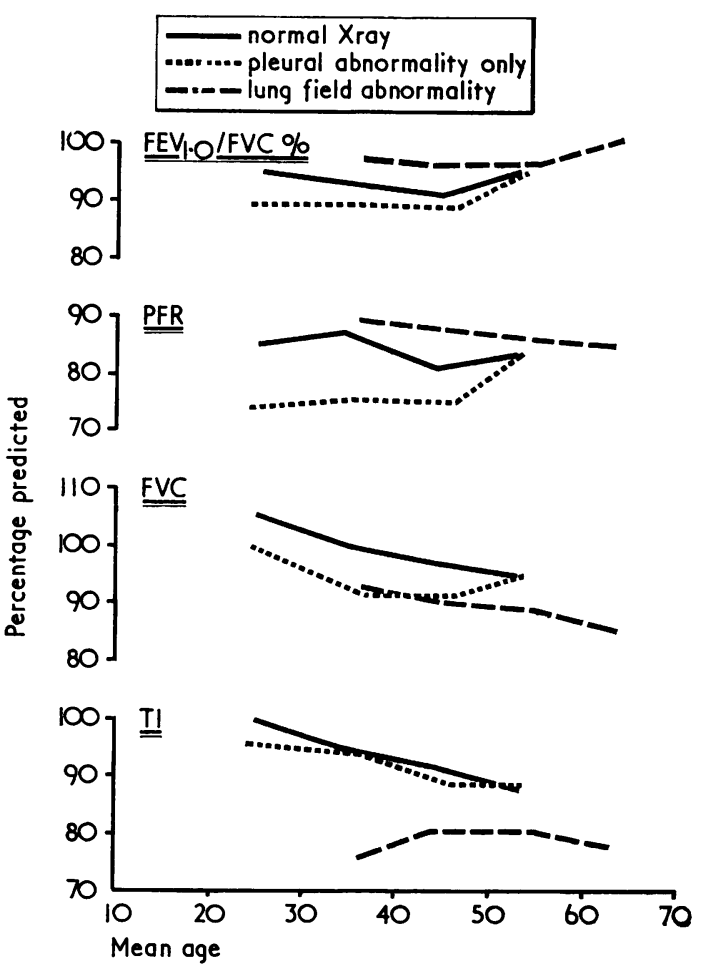

FIG. 2. Mean measurements of respiratory function in 10-year age groups in insulation workers with normal chest $x$-rays, pleural abnormality only, and lung field abnormality with or without pleural abnormality.

alone, $12(43 \%)$ had one additional factor, and there were none with more than one additional factor. Eight men with normal chest $x$-rays had rales and a low FVC and/or a low Tl with a normal FEV $_{1.0}$ FVC $\%$.

The 40-59 year age group A direct comparison of clinical findings and respiratory function between

TABLE 6

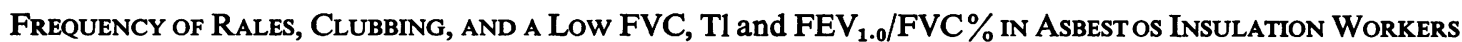
RELATED TO X-RAY FINDINGS

\begin{tabular}{|c|c|c|c|c|}
\hline & $\underset{x \text {-rays }}{\text { Normal }}$ & $\begin{array}{c}\text { Pleural } \\
\begin{array}{c}\text { abnormality } \\
\text { only }\end{array}\end{array}$ & & $\begin{array}{l}\text { Ig field } \\
\text { oleural } \\
\text { rmality }\end{array}$ \\
\hline $\begin{array}{l}\text { No. of men } \\
\text { Rales } \\
\text { Hyponychial angle }>205^{\circ} \\
\text { FVC }<80 \%, \text { FEV } \\
\text { Tl }<80 \%, \text { FEV } 80 \% \text { FVC } \% 80 \% \\
\text { FEV } 1.0 / \text { FVC } \%<80 \%\end{array}$ & $\begin{aligned} 162 & \\
15 & (9 \%) \\
0 & (6 \%) \\
9 & (6 \%) \\
31 & (19 \%) \\
19 & (12 \%)\end{aligned}$ & $\begin{aligned} 28 & \\
2 & \\
1 & \\
4 & (14 \%) \\
9 & (32 \%) \\
4 & (14 \%)\end{aligned}$ & $\begin{array}{r}62 \\
38 \\
7 \\
12 \\
29 \\
3\end{array}$ & $\begin{array}{l}(61 \%) \\
(11 \%) \\
(19 \%) \\
(57 \%) \\
(5 \%)\end{array}$ \\
\hline
\end{tabular}


men with normal and abnormal chest $x$-rays is invalid when applied to all the men in the survey, because of the preponderance of older men in the group with chest $x$-ray abnormality. The age group 40-59 years has been selected for detailed analysis: in this there were 65 men (mean age 46.5 years) with normal chest $x$-rays, 15 men (mean age $48 \cdot 1$ years) with pleural abnormality only, and 44 men (mean age $49 \cdot 0$ years) with lung field abnormality with or without pleural abnormality.

Clinical findings related to chest $x$-rays Results are shown in Table 7. More men had rales in the group with lung field abnormality than in the groups with pleural abnormality only and with normal chest $x$-rays; the difference was highly significant $\left(\chi^{2}=\right.$ $39.8, \mathrm{P}<0.0005$ ). Clubbing measured by a hyponychial angle $205^{\circ}$ or more in one or both forefingers was present in four men with lung field abnormality, in one man with pleural abnormality, but in no men with normal chest $x$-rays. The mean hyponychial angle was greater in men with lung field abnormality than in men with normai chest $x$-rays, but the difference was not statistically significant in either forefinger. There were more men with a history of severe dyspnoea (grade 3 to 5), cough, sputum, and cigarette smoking, especially heavy smoking, but fewer men with a history of wheeze, of the weather affecting the chest, and of exposure to 'limpet spraying' in the group with lung field abnormality than in the group with normal chest $x$-rays; there were more men with a history of mild dyspnoea (grade 2) in the group with pleural abnormality only than in the group with normal chest $x$-rays: the differences were not statistically significant. There were more men with asbestos bodies in the sputum and with past or present asbestos warts on the hands in the group with lung field abnormality than in the group with normal chest $x$-rays, but the differences were not statistically significant.

Respiratory function related to chest $x$-rays Men with lung field abnormality had a significantly lower mean FVC and Tl than men with normal chest $x$-rays (Table 8). There was no significant difference in measurements of respiratory function between men

\section{TABLE 8}

MEASUREMENTS OF RESPIRATORY FUNCTION IN INSULATION WORKERS AGED 40-59 YEARS RELATED TO X-RAY FINDINGS

\begin{tabular}{l|c|c|c}
\hline & $\begin{array}{c}\text { Mean for } \\
\text { normal } \\
\text { chest } \\
x-\text { rays }\end{array}$ & $\begin{array}{c}\text { Mean for } \\
\text { lung field } \\
\pm \text { pleural } \\
\text { abnormality }\end{array}$ & P \\
\hline Age (yr) & 46.5 & 49.0 & \\
Height (cm) & 168 & 167 & \\
FEV & \\
FVC (1.0) & 2.76 & 2.56 & n.s. \\
PFR (1/min) & 3.99 & 3.58 & $<0.01$ \\
TLC (1.) & 453 & 467 & n.s. \\
Tl (ml/mmHg) & 5.62 & 5.26 & n.s. \\
& 21.0 & 18.3 & $<0.02$ \\
\hline
\end{tabular}

TABLE 7

Clinical Findings, Cigarette Smoking, Asbestos Warts, Asbestos Bodies, and Exposure to Limpet SPRAYING IN INSUlation Workers AGEd 40 to 59 Years, Related to X-RAY Findings

\begin{tabular}{|c|c|c|c|c|c|c|}
\hline \multirow[b]{2}{*}{$\begin{array}{l}\text { No. of men } \\
\text { Rales } \\
\text { Hyponychial angle }>205^{\circ} \\
\text { Mean R. hyponychial angle } \\
\text { Mean L. hyponychial angle } \\
\text { Dyspnoea grade } 2 \\
\quad \text { grade } 3 \text { to } 5 \\
\quad \text { Total } \\
\text { Cough } \\
\text { Sputum } \\
\text { Wheeze } \\
\text { Weather affects chest } \\
\text { Cigarette smokers } \\
\text { Cig. smokers }>25 \text { daily } \\
\text { Asbestos warts on hands } \\
\text { Asbestos bodies in sputum } \\
\text { Limpet spraying }\end{array}$} & \multicolumn{2}{|c|}{ Normal x-rays } & \multicolumn{2}{|c|}{$\begin{array}{c}\text { Pleural } \\
\text { abnormality } \\
\text { only }\end{array}$} & \multicolumn{2}{|c|}{$\begin{array}{c}\text { Lung field } \\
\pm \text { pleural } \\
\text { abnormality }\end{array}$} \\
\hline & $\begin{array}{c}65 \\
8 \\
0 / 16 \\
185^{\circ} \\
186^{\circ} \\
20 \\
13 \\
33 \\
43 \\
44 \\
46 \\
20 \\
45 \\
12 \\
41 / 62 \\
17 / 51 \\
19\end{array}$ & $\begin{array}{l}(31 \%) \\
(20 \%) \\
(51 \%) \\
(66 \%) \\
(68 \%) \\
(71 \%) \\
(31 \%) \\
(69 \%) \\
(18 \%) \\
(66 \%) \\
(33 \%) \\
(29 \%)\end{array}$ & $\begin{array}{c}15 \\
1 \\
1 / 14 \\
185^{\circ} \\
186^{\circ} \\
8 \\
2 \\
10 \\
9 \\
13 \\
9 \\
3 \\
11 \\
3 \\
9 / 14 \\
2 \\
3\end{array}$ & $\begin{array}{l}(7 \%) \\
(7 \%) \\
(53 \%) \\
(13 \%) \\
(67 \%) \\
(60 \%) \\
(87 \%) \\
(60 \%) \\
(20 \%) \\
(73 \%) \\
(20 \%) \\
(64 \%) \\
(13 \%) \\
(20 \%)\end{array}$ & $\begin{array}{c}44 \\
25 \\
4 / 42 \\
186^{\circ} \\
188^{\circ} \\
14 \\
12 \\
26 \\
33 \\
35 \\
29 \\
10 \\
35 \\
13 \\
36 / 42 \\
15 / 38 \\
10\end{array}$ & $\begin{array}{l}(57 \%) \\
(10 \%) \\
(32 \%) \\
(27 \%) \\
(59 \%) \\
(75 \%) \\
(80 \%) \\
(66 \%) \\
(23 \%) \\
(80 \%) \\
(30 \%) \\
(86 \%) \\
(40 \%) \\
(23 \%)\end{array}$ \\
\hline
\end{tabular}


with pleural abnormality only and men with normal chest $x$-rays.

Relationship between smoking and respiratory function Men were graded as non-smokers, ex-smokers, and smokers of 1 to 14,15 to 24 , and 25 or more cigarettes daily, or a corresponding amount of pipe tobacco. The relationships between grades of smoking and measurements of respiratory function in men with normal chest $x$-rays or with lung field abnormality are shown in Table 9. The results of measurements of respiratory function in non- and ex-smokers combined, and in the grades of smokers combined, are shown in Table 10 and Figure 3. The group of men with pleural abnormalities only was too small to be analysed in this way. The mean results of respiratory function tests were within the normal range in non-smokers and ex-smokers, even in the presence of lung field abnormality in the chest $x$-rays. The mean PFR, FVC, and Tl, and in the group with normal chest $x$-rays the mean $\mathrm{FEV}_{1.0} / \mathrm{FVC} \%$, were lower in smokers than in non-smokers and ex-smokers, the difference being greatest in the PFR and Tl in men with normal chest $x$-rays and in the FVC and Tl in men with lung field abnormality. The mean standing height was less in smokers than in the group of nonsmokers and ex-smokers combined, and this was statistically significant both in men with normal chest $x$-rays $(P<0.05)$ and in men with lung field abnormality $(P<0.02)$.

Relationship between dyspnoea, rales, clubbing, and respiratory function. This is shown in Table 10 . The presence of severe dyspnoea was associated with impairment of the mean PFR, FVC, and Tl, with the PFR more affected in men with normal $x$-rays and the Tl more affected in men with lung field abnormality. Men with severe dyspnoea and lung field abnormality tended to be short in stature. There were eight men with normal chest $x$-rays who had rales and they had a slightly lower mean FVC and Tl and a markedly lower mean PFR than the 25 men with lung field abnormality who had rales.

\section{Discussion}

The presence of any two of the following five factors in anyone who has been exposed to asbestos is held to be strongly suggestive of asbestosis: chest $x$-ray abnormality (parenchymatous or pleural), breathlessness, basal rales, finger clubbing, and a reduced transfer factor (Ministry of Social Security, 1967). In addition, the restrictive defect in asbestosis causes a reduction in $\mathrm{FEV}_{1.0}$, FVC or VC, RV and TLC; the pulmonary compliance is low; expiratory airways collapse is reduced so that the $\mathrm{FEV}_{1.0} / \mathrm{FVC} \%$ and PFR are well maintained or increased; the $\mathrm{Po}_{2}$ tends to be low and the $\mathrm{A}-\mathrm{a} \mathrm{Po}_{2}$ difference to be raised (Thomson, Pelzer, and Smither, 1965; Wallace and Langlands, 1971).

In the present survey, the incidence of chest $x$-ray abnormality of the lung fields or pleura increased from $13 \%$ in men who had been exposed to asbestos for less than 10 years to $85 \%$ in men who had been exposed for $\mathbf{3 0}$ or more years. Men with lung field abnormality had been exposed to asbestos for an average of five years longer than men in the same age group who had normal chest $x$-rays. Two-thirds

TABLE 9

EFFect of Smoking on Measurements of Respiratory Function in Asbestos Insulation WORKERS AGED 40-59 YEARS

\begin{tabular}{|c|c|c|c|c|c|c|}
\hline & \multirow[b]{2}{*}{ No. } & \multirow[b]{2}{*}{$\begin{array}{c}\text { Mean } \\
\text { Ht. } \\
(\mathrm{cm})\end{array}$} & \multicolumn{4}{|c|}{$\%$ Predicted } \\
\hline & & & $\begin{array}{c}\text { Mean } \\
\text { FEV } 1.0 \% \\
F V C\end{array}$ & $\begin{array}{c}\text { Mean } \\
\text { PFR }\end{array}$ & $\begin{array}{c}\text { Mean } \\
\text { FVC }\end{array}$ & $\begin{array}{c}\text { Mean } \\
T l\end{array}$ \\
\hline $\begin{array}{l}\text { Normal x-rays } \\
\text { Non-smokers } \\
\text { Ex-smokers } \\
1-14 \text { cigarettes daily } \\
15-24 \text {,', ", cigarettes daily } \\
25 \text { or more }\end{array}$ & $\begin{array}{r}9 \\
11 \\
6 \\
27 \\
12\end{array}$ & $\begin{array}{l}171 \\
170 \\
167 \\
168 \\
168\end{array}$ & $\begin{array}{r}100 \\
93 \\
92 \\
93 \\
88\end{array}$ & $\begin{array}{l}90 \\
94 \\
69 \\
83 \\
72\end{array}$ & $\begin{array}{r}97 \\
104 \\
88 \\
95 \\
95\end{array}$ & $\begin{array}{r}93 \\
101 \\
79 \\
87 \\
80\end{array}$ \\
\hline $\begin{array}{l}\text { Radiological lung field abnorm } \\
\pm \text { pleural abnormality } \\
\text { Non-smokers } \\
\text { Ex-smokers } \\
1-14 \text { cigarettes daily } \\
15-24 \text { ", cigarettes daily } \\
25 \text { or more cigar }\end{array}$ & $\begin{array}{r}4 \\
5 \\
9 \\
13 \\
13\end{array}$ & $\begin{array}{l}171 \\
172 \\
167 \\
164 \\
166\end{array}$ & $\begin{array}{l}98 \\
97 \\
99 \\
97 \\
95\end{array}$ & $\begin{array}{l}91 \\
90 \\
91 \\
87 \\
84\end{array}$ & $\begin{array}{r}105 \\
90 \\
88 \\
88 \\
86\end{array}$ & $\begin{array}{r}101 \\
85 \\
81 \\
70 \\
80\end{array}$ \\
\hline
\end{tabular}


TABLE 10

Measurements of Respiratory Function in Asbestos Insulation Workers aged 40-59 Years Related to Smoking Habit, Dyspnoea, Rales, and Clubbing

\begin{tabular}{|c|c|c|c|c|c|c|}
\hline & \multirow[b]{2}{*}{ No. } & \multirow[b]{2}{*}{$\begin{array}{l}\text { Mean } \\
\mathrm{Ht} . \\
(\mathrm{cm})\end{array}$} & \multicolumn{4}{|c|}{$\%$ Predicted } \\
\hline & & & $\begin{array}{c}\text { Mean } \\
\frac{F E V_{1.0} \%}{F V C}\end{array}$ & $\begin{array}{l}\text { Mean } \\
\text { PFR }\end{array}$ & $\begin{array}{l}\text { Mean } \\
\text { FVC }\end{array}$ & $\begin{array}{c}\text { Mean } \\
T I\end{array}$ \\
\hline $\begin{array}{l}\text { Normal } x \text {-rays } \\
\text { All }\end{array}$ & 65 & 168 & 93 & 83 & 97 & 89 \\
\hline $\begin{array}{l}\text { Non and ex-smokers } \\
\text { Smokers }\end{array}$ & $\begin{array}{l}20 \\
45\end{array}$ & $\begin{array}{l}170 \\
168\end{array}$ & $\begin{array}{l}95 \\
92\end{array}$ & $\begin{array}{l}93 \\
79\end{array}$ & $\begin{array}{r}101 \\
93\end{array}$ & $\begin{array}{l}98 \\
82\end{array}$ \\
\hline $\begin{array}{l}\text { No dyspnoea } \\
\text { Dyspnoea grade } 2 \\
\text { Dyspnoea grade } 3 \text { to } 5\end{array}$ & $\begin{array}{l}32 \\
20 \\
13\end{array}$ & $\begin{array}{l}170 \\
167 \\
166\end{array}$ & $\begin{array}{l}93 \\
94 \\
91\end{array}$ & $\begin{array}{l}85 \\
87 \\
70\end{array}$ & $\begin{array}{l}99 \\
96 \\
89\end{array}$ & $\begin{array}{l}95 \\
82 \\
85\end{array}$ \\
\hline $\begin{array}{l}\text { Rales grade } 1 \\
\text { Rales grade } 2\end{array}$ & $\begin{array}{l}5 \\
3\end{array}$ & $\begin{array}{l}165 \\
164\end{array}$ & $\begin{array}{r}103 \\
92\end{array}$ & $\begin{array}{l}76 \\
60\end{array}$ & $\begin{array}{l}83 \\
82\end{array}$ & $\begin{array}{l}76 \\
67\end{array}$ \\
\hline $\begin{array}{l}\text { Radiological lung field abnormality } \\
\text { All }\end{array}$ & 44 & 167 & 98 & 87 & 90 & 80 \\
\hline $\begin{array}{l}\text { Non and ex-smokers } \\
\text { Smokers }\end{array}$ & $\begin{array}{r}9 \\
35\end{array}$ & $\begin{array}{l}171 \\
165\end{array}$ & $\begin{array}{l}97 \\
97\end{array}$ & $\begin{array}{l}92 \\
87\end{array}$ & $\begin{array}{r}100 \\
88\end{array}$ & $\begin{array}{l}92 \\
76\end{array}$ \\
\hline $\begin{array}{l}\text { No dyspnoea } \\
\text { Dyspnoea grade } 2 \\
\text { Dyspnoea grade } 3 \text { to } 5\end{array}$ & $\begin{array}{l}18 \\
14 \\
12\end{array}$ & $\begin{array}{l}168 \\
168 \\
162\end{array}$ & $\begin{array}{r}100 \\
95 \\
95\end{array}$ & $\begin{array}{l}92 \\
81 \\
83\end{array}$ & $\begin{array}{l}91 \\
87 \\
89\end{array}$ & $\begin{array}{l}84 \\
77 \\
74\end{array}$ \\
\hline $\begin{array}{l}\text { Rales grade } 1 \\
\text { Rales grade } 2\end{array}$ & $\begin{array}{l}14 \\
11\end{array}$ & $\begin{array}{l}166 \\
166\end{array}$ & $\begin{array}{l}99 \\
93\end{array}$ & $\begin{array}{l}84 \\
88\end{array}$ & $\begin{array}{l}89 \\
90\end{array}$ & $\begin{array}{l}78 \\
72\end{array}$ \\
\hline Hyponychial angle $>205^{\circ}$ & 4 & 164 & 98 & 88 & 88 & 68 \\
\hline
\end{tabular}

Percentoge predicted

$\begin{array}{llll}70 \quad 80 & 90 & 100\end{array}$

FVC

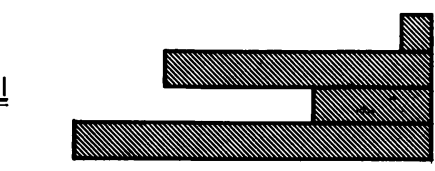

$\underline{\underline{\text { FEV }}}$.O/FVC \%

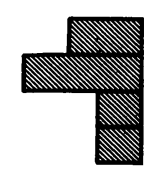

$\underline{\underline{P F R}}$

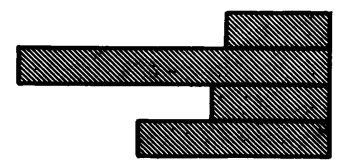

NS)

$S\}$ normal Xray

NS\{lung field s\}abnormality

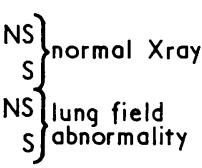

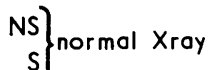

NS lung field

s) abnormality

NS\}normol Xroy

NS\{lung field

s\}abnormality of the men with lung field abnormality had pleural abnormality as well. Pleural abnormality as an isolated phenomenon predominated in men who had abnormal chest $x$-rays with less than 10 years' exposure, but was rare without lung field abnormality in men with 30 or more years' exposure. In a survey of insulation workers in New York by Selikoff, Churg, and Hammond (1965) any chest $x$-ray abnormality in men with less than 10 years' exposure usually consisted of minimal parenchymal infiltration without pleural abnormality, and Selikoff (1965) found that pleural calcification was very rare in men whose first exposure was less than 20 years previously. The relatively high incidence of pleural abnormality, with calcification in two cases, in men with a short occupational exposure in our series may be due to

FIG. 3. Mean measurements of respiratory function compared with $100 \%$ predicted in non- or ex-smokers (NS) and smokers (S) with normal $x$-rays, and with lung field abnormality with or without pleural abnormality. 
contact with asbestos dust in childhood through relatives who were insulation workers.

Sheers and Templeton (1968) studied dockyard workers with varying degrees of exposure to asbestos. In their heavily exposed group, which included insulation workers, the incidence of chest $x$-ray abnormality related to duration of exposure was similar to the incidence in our survey, but the proportion of men with pleural abnormality alone was much higher and only $20 \%$ of abnormal chest $x$-rays showed lung field abnormality compared with $69 \%$ in our survey. In their groups with intermittent or light exposure, the incidence of chest $x$-ray abnormality was less and was almost confined to pleural abnormality. The higher proportion of chest $x$-rays with pleural abnormality in their survey is difficult to explain; it may reflect differences in the degree of exposure or in the type of asbestos to which the men had been exposed. It was not possible to assess the individual degree of exposure to asbestos dust in men in our survey, and no correlation was found between a history of having done 'limpet spraying' of asbestos and the incidence of chest $x$-ray abnormality.

Of men with lung field abnormality in the chest $x$-ray, $61 \%$ had rales and $11 \%$ had finger clubbing. In the $40-59$ year age group there was a significantly higher incidence of rales and a significantly lower FVC and Tl compared with men with normal chest $x$-rays, but no statistically significant difference in the frequency of dyspnoea although there was a tendency for the dyspnoea to be more severe. Men with only pleural abnormality in the chest $x$-ray formed a smaller group, and the differences between them and men with normal chest $x$-rays did not reach statistical significance; the frequency of rales and clubbing was the same in men with pleural abnormality as in men with normal chest $x$-rays but the frequency of dyspnoea was higher: respiratory function tests showed a lower mean FEV 1.0/FVC $\%$, PFR and FVC, but a mean Tl which did not differ from that of men with normal chest $x$-rays. The difference in the pattern of abnormal lung function between men with lung field abnormality and men with pleural abnormality only must reflect the fact that the lung parenchyma was involved by fibrosis in the former group, causing an impairment in vital capacity and in gas transfer but a decrease in expiratory airways resistance which caused ventilatory function to be well maintained. Where there was fibrosis or calcification of the pleura without appreciable fibrosis of the lung parenchyma there was a tendency to impairment in vital capacity and in ventilatory function without impairment in gas transfer. The presence of asbestos bodies in the sputum is not diagnostic of asbestosis, but these and asbestos warts on the hands may indicate a higher exposure to asbestos dust; they were commoner in men with lung field abnormality than in men with normal chest $x$-rays. Where finger clubbing was present there was usually a marked difference between the hyponychial angles of the left and right forefingers, the left being more clubbed.

There was considerable impairment of lung function in smokers compared with non-smokers; indeed there was a lower mean FVC and Tl in smokers with normal chest $x$-rays than in nonsmokers with lung field abnormality in their chest $x$-rays. Selikoff, Hammond, and Churg (1968) have shown that smoking and exposure to asbestos have an additive effect in causing lung cancer, and the present study showed that smoking and exposure to asbestos also have an additive effect in causing impairment of lung function in respect of vital capacity and gas transfer.

Of factors held to be suggestive of asbestosis, we found that basal rales were most often associated with lung field abnormality in the chest $x$-ray. Clubbing occurred less frequently. Dyspnoea on exertion was a common complaint whether lung field abnormality was present or not. FVC and Tl were significantly lower where there was lung field abnormality, but these tests of lung function were often difficult to interpret in the individual suspected of having an early asbestosis because of the wide range of normality and the marked effect of smoking habits. Two or more of the three factors of rales, finger clubbing, and an abnormality of lung function of the type suggestive of asbestosis (a low FVC or a low $\mathrm{Tl}$ with a normal $\mathrm{FEV} \mathrm{1}_{1.0} / \mathrm{FVC} \%$ ) were present in $25(40 \%)$ men with lung field abnormality with or without pleural abnormality in the chest $x$-ray, in no men with pleural abnormality only, and in only eight $(3 \%)$ men with normal chest $x$-rays. It is possible that some or all of these eight men may have early asbestosis. A deterioration in lung function is said often to precede the development of definite radiological abnormality due to asbestosis (Williams and Hugh-Jones, 1960), but in view of the relationship between smoking and lung function, any abnormality in lung function found in a single examination in cigarette smokers with normal chest $x$-rays should be interpreted with caution.

The presence of rales, or the rapid deterioration in lung function over a period of time found by Hunt (1965) in some asbestos workers, may be a more reliable indication of early asbestosis.

Up to now there has been no regular medical supervision of insulation workers but arrangements for voluntary medical examinations and chest $x$-rays are being made by the Ministry of Health. Supervision of working conditions has also been improved under new regulations. Preventive measures for men using asbestos should include protective clothing and masks with filters or a compressed air supply. Other workmen should be excluded from the 
area where asbestos is being used and the dust should be collected and disposed of after the work has been completed (Harries, 1968). Wherever possible, other insulating materials, such as fibreglass which do not affect the lungs, should be substituted for asbestos.

We wish to thank Professor O. L. Wade for giving us facilities and encouragement, Dr. J. C. Gilson for advice and supervision, Dr. J. C. Gilson, Professor P. C. Elmes, and Dr. J. O. Y. Cole for reading the $x$-rays, Dr. Deidre Bell for looking for asbestos bodies in the sputum, Dr. J. D. Merett for writing a computer programme and for advice about the statistical analysis of results, Mr. J. Collins, Miss A. Stevenson, and Miss S. Wheeler for technical help, and Miss M. Wilkinson for typing the manuscript. Our thanks are due to the asbestos insulation workers and their trade union and employers for their cooperation.

\section{References}

Cotes, J. E. (1965). Lung Function: Assessment and Application in medicine, 1st ed., pp. 341-342. Blackwell Scientific publications, Oxford.

Harries, P. G. (1968). Asbestos hazards in naval dockyards. Ann. occup. Hyg., 11, 135-145.

Hunt, R. (1965). Routine lung function studies on 830 employees in an asbestos processing factory. Ann. N.Y. Acad. Sci., 132, 406-420.
Medical Research Council (1960). Standardized questionnaires on respiratory symptoms. Brit. med.J., 2, 1665.

Ministry of Social Security (1967). Pneumoconiosis and Allied Occupational Chest Diseases, p. 34. H.M.S.O., London.

Regan, Gillian M., Tagg, Beryl, and Thomson, M. L. (1967). Subjective assessment and objective measurement of finger clubbing. Lancet, 1, 530-532.

Selikoff, I. J. (1965). The occurrence of pleural calcification among asbestos insulation workers. Ann. N.Y. Acad. Sci., 132, 351-367.

- Churg, J., and Hammond, E. C. (1965). The occurrence of asbestosis among insulation workers in the United States. Ann. N.Y. Acad. Sci., 132, 139-155.

-, Hammond, E. C., and Churg, J. (1968). Asbestos exposure, smoking, and neoplasia. J. Amer. med. Ass., 204, 106-112.

Sheers, G., and Templeton, Ann R. (1968). Effects of asbestos in dockyard workers. Brit. med. J., 3, 574-579.

Sluis-Cremer, G. K., and Theron, C. P. (1965). Radiological and pathological correlations in asbestosis in the Republic of South Africa and the United Kingdom. I. A proposed radiological classification of asbestosis. Ann. N.Y. Acad. Sci., 132, 373-378.

Thomson, M. L., Pelzer, Anne-Marie, and Smither, W. J. (1965). The discriminant value of pulmonary function tests in asbestosis. Ann. N.Y. Acad. Sci., 132, 421-436.

Wallace, W. F. M., and Langlands, Jean H. M. (1971). Insulation workers in Belfast. 1. Comparison of a random sample with a control population. Brit. J. industr. Med., 28, 211-216.

Williams, R., and Hugh-Jones, P. (1960). Significance of lung function changes in asbestosis. Thorax, 15, 109-119.

Received for publication July 21, 1970. 